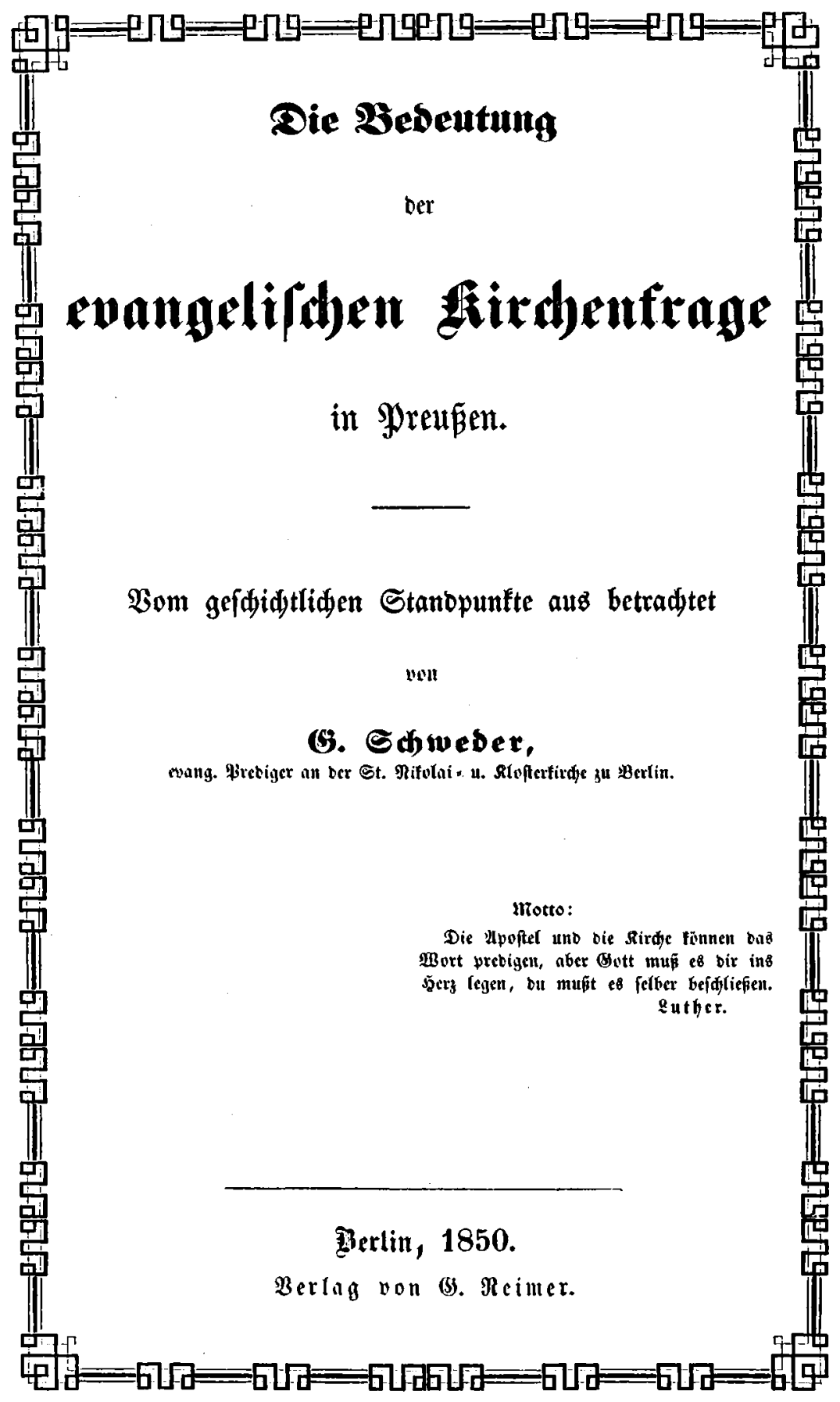





\title{
Die Bedentung
}

\section{ber

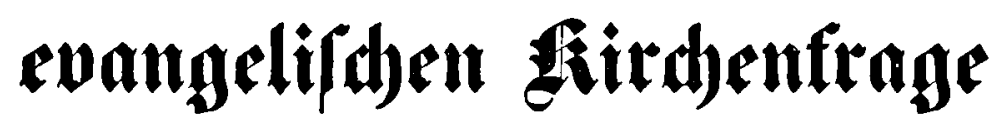

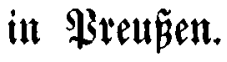

Bom gefdiøtliden Stanbpunfte aus betradtet

volt

\section{(9. Ochweder,}

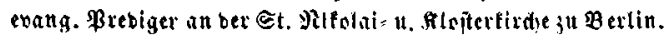

\section{motto:}

Die Mroftel unb bie, Rirhe tönnen bas Wort wrebigett, aber (sott mus es Dir ins \$ery legen, bu mus̄t es felber beíllepiet.

suticr.

\author{
Berlin, 1850.

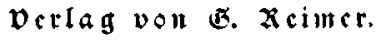


